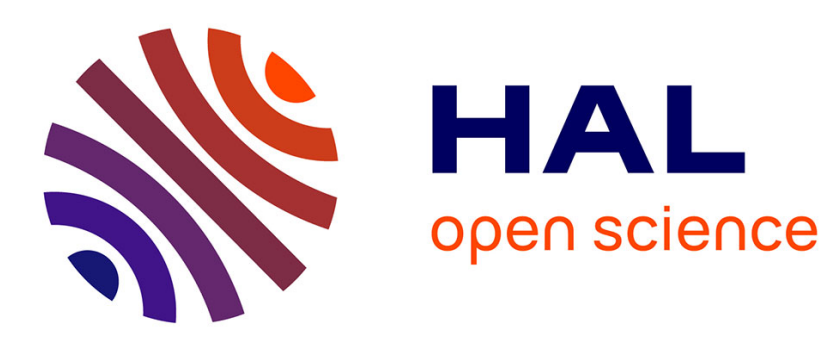

\title{
Fragile Intimacies: Marriage and Love in the Palestinian Camps of Jordan (1948-2001)
}

\author{
Stephanie Latte Abdallah
}

\section{To cite this version:}

Stephanie Latte Abdallah. Fragile Intimacies: Marriage and Love in the Palestinian Camps of Jordan (1948-2001). Journal of Palestine Studies, 2009, 38 (4 (summer)), pp.47 - 62. 10.1525/jps.2009.38.4.47 . hal-02320126

HAL Id: hal-02320126

https://hal-sciencespo.archives-ouvertes.fr/hal-02320126

Submitted on 14 Dec 2020

HAL is a multi-disciplinary open access archive for the deposit and dissemination of scientific research documents, whether they are published or not. The documents may come from teaching and research institutions in France or abroad, or from public or private research centers.
L'archive ouverte pluridisciplinaire HAL, est destinée au dépôt et à la diffusion de documents scientifiques de niveau recherche, publiés ou non, émanant des établissements d'enseignement et de recherche français ou étrangers, des laboratoires publics ou privés. 


\title{
Fragile INTIMACIES: MARRIAGE and Love in the Palestinian CAMPS OF JORDAN (1948-2001)
}

\author{
STÉPHANie LaTte ABDAllah
}

\begin{abstract}
This article focuses on conjugal love as an articulated, lived emotion; on relationships between spouses within the context of the family; and on how these emotions and relations have changed over time in Palestinian refugee camps in Jordan. Based on interviews with four generations of Palestinian camp women, the article charts evolving marital patterns and attitudes toward marriage in relation to changing political circumstances and diverse influences. Particular emphasis is given to the third generation and the emergence of individualization of choice and its consequences. The influence of the family and the role of protection in the formation of conjugal bonds are also addressed.
\end{abstract}

Although FeELINGS AND EMOTIONs inform almost all social interactions, not to mention individual and group agency, they have traditionally been curiously absent from studies of marriage patterns and the history of the marital bond. Since the mid-1980s, some groundbreaking works have appeared that illuminate the social context and patterning of emotion and sentiment-showing how they shape power relations and underpin symbolic exchanges-but these studies focus mainly on Europe and the West. ${ }^{1}$ When it comes to the Middle East, the role of emotions remains largely ignored.

This article will focus on conjugal love as an articulated, lived emotion; on relationships between spouses within the context of the family; and on how these emotions and relations have changed over time in Palestinian refugee camps in Jordan. In the refugee camps, the weight of traumatic collective history and "community-becoming" has deeply affected individual stories and agencies. Here, politics and social relations, as well as the public and the private, become intertwined. This is especially the case when it comes to love, marriage, and the family - a space of negotiation and movement between the domestic, the social, and the political, ${ }^{2}$ and the principal domain where love can be lived and expressed. ${ }^{3}$

To trace the historical changes that have affected marriage and the emergence of conjugal love as a social value, I focus on four generations of women

Stéphanie Latte Abdallah is a research fellow at the Institut de Recherche et d'Études sur le Monde Arabe et Musulman, Centre National de la Recherche Scientifique, Aix-enProvence, and a lecturer in history at the University of Provence. 
interviewed on the cusp of the twenty-first century. Generations here are defined as "groups of persons who have lived through the same historical periods and political and economic situations at the same point in their life cycle." ${ }^{4}$ The women born in or before 1938 are referred to as the "old generation" or the "generation of Palestine"; those born between 1939 and 1953 are called the "daughters of the catastrophe" (banat al-nakba), with reference to the 1948 exodus. No widely accepted names have been adopted to designate the third or fourth generations, although the third (women born between 1954 and 1968) has been called the "Saudi generation," and the fourth (women born between 1969 and 1983) is sometimes humorously referred to as the "television or satellite generation." Although the politics and social conditions of exile differ in Jordan and Lebanon, the generational prism I adopt partly echoes Rosemary Sayigh's groundbreaking study of the impact of exile on gender relations in Shatila camp in Lebanon, which referenced three generations. 5

The interviews that form the basis of this study were mostly collected during fieldwork, conducted primarily in two camps in Jordan: the Jabal Hussein camp in Amman and the Gaza camp in Jerash, north of Amman. ${ }^{6}$ The Jabal Hussein camp was created after 1948 and is today part of the urban configuration of the Jordanian capital. Like most of the refugees in the country, the camp's inhabitants, who came mainly from villages and small towns, have been Jordanian nationals since the 1950s. The Gaza camp was established in 1967 for refugees from the Gaza Strip displaced to Jordan after the 1967 war; most of the camp's inhabitants had originally been Bedouins from Bir al-Saba in the Negev. As former Gazans, most of the Jerash camp's inhabitants do not have Jordanian nationality.

\section{The Oldest Generations: Family Love versus the Conjugal BOND}

The "Palestine generation," or women born before 1938, were young at the time of the 1948 exodus. Most of them were already married, some pregnant, or with one or two babies or small children. These women had not chosen their husbands; the decision had been made by their father or, if he was deceased, by a brother or uncle, sometimes with the agreement of the extended family. For the most part, the women had not seen their husband before the wedding.

All the women of this generation in my study-whether they were of Bedouin origin, from a village, or from a small town-had at one point been married, generally very young. In pre-1948 Palestine, marriage was virtually universal. ${ }^{7}$ Approximately two-thirds were wed before the age of fifteen, and about a quarter of those as early as twelve or thirteen. Unions did not split up; marriages ended when the husband died. At the time of my research, these women were over seventy years old and almost two-thirds were widows. ${ }^{8}$ 
Most were illiterate; only two out of eleven (both from urban backgrounds and with close relationships with their father) had a few years of elementary school. More than half had worked, helping their husbands in the early years of exile or working periodically (in agriculture, sewing, and various petty jobs) to contribute to the household expenses.

In their accounts, all these women took marriage for granted: it was not special, but the result of naseeb (fate, luck, or destiny): "It was like everybody else," said Umm Khalil. Marriage was rarely mentioned spontaneously unless it represented a moment of personal gratification for the narrator. This was the case for Umm Muhammad, whose husband married her against his family's will, thus breaking with prevailing social norms. He had fallen in love with her at first sight during their first exile in the Gaza Strip:

At that time when we got married, we did not have . . . something . . . for example like love. The hamula [clan] looked for the bride. They [her husband's family] wanted him to take his uncle's daughter [bint 'am]. But it happened that she had no beauty, and he told them, "If you give her to me and you build a house for us to live together, I will leave it all and go live in Israel." So his uncle said that it was shameful ('ayb) for his daughter. One day of those days, I was on a visit to neighbors of his family and he saw me there. When he saw me, he told his parents, "There is a girl, I do want her. If you don't give her to me, I will travel I do not know where." You see how is naseeb? They [his parents] came to our house the day of Eid. They were thinking of somebody else to be the bride, ${ }^{9}$ one of my older sisters who was divorced. They told him, "She is the bride." We made tea with red sugar, and I [served] it. Then his parents asked him, "Well, Hussein?" He said, "I want her. That's it." 10

When I asked her opinion about this marriage, she replied, "They did not ask my opinion, it was shameful ('ayb)." Umm Muhammad's marriage was known to be happy and socially rewarding, but among her generation only the love of men was directly evoked; only with the passage of years did some women admit such feelings:

\footnotetext{
"But inside, what did you think?"

"Inside, really, I loved him [she laughs, embarrassed]. He was handsome and he had a strong personality. And he was an ustaz [a school teacher]."
}

Most of the "Palestine generation" women did not mention the story of their marriage. Sayigh, writing about this same generation in Shatila camp, attributes 
this silence mainly to shame at any expression of sexuality, to the point of editing marriage out of the narrative. ${ }^{11}$ I would add that the subject is also avoided because it is not generally a memory associated with a positive selfimage and identity: most marriages were not chosen, and many were unhappy or overwhelmed by the harsh conditions of exile.

In most marriages, especially at their beginnings, familial (filial or sibling) love was more important than love between spouses. A particularly dramatic example of the primacy of family love is the story of a man who had been in love with his first wife, but divorced her for the sake of his sister's wellbeing, later marrying another woman whom he did not love:

He dearly loved Soraya, his first wife. He was bringing everything to her, he even brought her a music box. He was the first to bring one to the village. He was also the first one to break the rule and divorce. But his sister was tired [and by breaking his marriage, his sister would get a divorce $\left.{ }^{12}\right] .{ }^{13}$

There are many indications in these narratives of the greater value given to family ties over matrimonial links, and to life before marriage, especially in marriages contracted around the 1948 exodus. In their accounts, what mattered most at this time of harsh and painful rupture with their past life in Palestine was the positive social value they could derive from marriage, as measured by the amount of maber (the dower, the bride price paid by the groom or his family to the bride, often paid to the bride's family in practice), the gifts received, the husband's social status and ability to fulfill his role as breadwinner, and the families' genealogical proximity. Hajji Myriam, for example, was strongly affected when her husband took a second wife. She was in her twenties at the time. Though she and her husband belonged to different clans, she invented a fictional kinship between them. It was a way to evoke her love for him and their special bond, love between relatives being more valued and overtly talked about than conjugal love:

Yes, he is a relative, he is closer to me than to her [the second wife]. I am closer to him (ana aghrablbu). She is from another Dawaymeh family.

Later, in response to a question, she contradicted herself on their genealogical proximity, admitting that she and her husband were not related, but added, "What brings us close is that we make one, we were drinking coffee together, we've been doing everything together." 14

The overwhelming importance of the family of origin as far as feelings are concerned is also evident in Umm Mustapha's story. She married in Jabal 
Hussein camp at the beginning of the 1950s, but the relationship she speaks of most is the special bond she shared with her father, his love for her, and her life before 1948 and before her marriage. The fact that her father, who before their exile owned cultivated lands and worked in Jaffa, had a much higher social status than her husband may have contributed to her emphasis on this period of her life.

For this generation of women, especially those of peasant background, exile meant the loss of the crucial economic role they played in the villages alongside men: this sudden change implied not only a loss of personal resources but also confinement in the house. This sharp division between men's and women's activities and spaces broke the rhythm of shared times between husbands and wives. Umm Adnan is very clear on this point:

Before, we used to work together, women, husbands, and children ... It was not like here, the man goes out and the woman stays home ... We were going out together, we were happy. ${ }^{15}$

For most of this generation (and for some of the next), collective becoming, family history, and above all the traumatic history of 1948 overwhelm individual histories. As shown in Umm Jamal's story below, the decisive events are collective, political, and social; the stories are told as if they were drawn in the historical rupture of exile. Her story also shows the importance of the way familial love was displayed and perceived through marriage choices and practices that contributed to the construction of self-esteem and a positive selfimage in women who were marrying very young, some while still children.

Umm Jamal belonged to an influential clan from the village of Dawaymeh but was an orphan. Her marriage was decided by her uncle. From her account, it was apparent that she suffered less from her arranged marriage than she did from the fact that her uncle did not arrange for her to receive maber, which in her eyes showed that she was married without her family's love:

At home, before we left in 1948, when I got married, girls were at five hundred Palestinian pounds [for the maher]. And the groom bought the gold, the wedding dress (thob), and the trousseau. They [the families] used to share to buy the furniture. I did not get a maber, they did not give me one. There was another [woman]. I married by exchange. I am a badileh. My uncle gave me to my husband, and since he himself did not have a wife, he married my husband's sister. We [my family] took his sister and he [my husband] took me. My uncle did not give [get] me any maher. He bought the wedding dress, a few clothes, and that's all. I was small, I saw girls like me getting married. I did not say anything, I did not have brothers or a father [to protect me]. But still I was 
happy, I was at home on my land, but after the exodus [bijra], everything changed ... and my uncle, the one who married me off, died as a martyr [shahid], killed by the Israelis in $1948 .{ }^{16}$

The "daughters of the Nakba," the second generation, were born in the decade before the loss of Palestine and during the first years of exile (193953). They grew up in the camps during what has been called the "refugee years" or "lost years," when energies were entirely consumed by poverty and survival. This "forgotten" generation of women is also a generation of transition. Like the "Palestine generation," almost all the "daughters of the Nakba" married, for the most part reproducing pre-1948 matrimonial practices. They married young (at the end of the 1950s or during the 1960s), but not as early as the previous generation: over three-quarters married before the age of twenty, and more than a third before the age of sixteen. Again, most of the unions were chosen by the family, often by fathers or brothers. Only two of the women made a personal choice, and one of these was a second marriage contracted in adulthood. Most of the women married before education became widely available in Jordan, especially for women, so they were poorly educated; more than half were illiterate. They were also caught between the years of dislocation and lack of political direction and the rise of the Palestinian nationalist movement in the late 1960s. In contrast to the succeeding generation, however, they did not experience any of the benefits brought by the resistance.

Of the four generations I studied, the conjugal bond for these women provided the least protection and economic security. At the time of my fieldwork, when the "daughters of the Nakba" ranged from fifty-five to seventy years of age, half were heads of households, mostly due to widowhood. ${ }^{17}$ A number of their husbands had become involved in the Palestinian revolution after the 1967 war, and some followed the movement to Lebanon, where it moved after being expelled from Jordan in 1971. As a result, some of these women became widows early (a frequent consequence of Jordan's 1970-71 civil war and later of the civil war in Lebanon), and some were left to raise their children on their own due to their husband's military mobilization. In other cases, their lack of support resulted from the persistence of unions with much older men, who either died or became chronically infirm or ill.

These women resisted silently, struggling to cope with the harsh conditions of the camps in the first decades and working in precarious and low-skill jobs for long periods of time. Their contribution to the national movement is mainly recognized through their traditional roles as mothers, caregivers, and transmitters of Palestinian cultural identity through daily practices such as cooking and crafts. But unlike the previous generation, which is often represented as one of a golden age and as the living memory of Palestine, this generation is mainly perceived as one of passive or subdued personalities worn down by exile. 


\section{The Third Generation: Marital Love as A Wished Feeling AND VALUE}

In sharp contrast to the "daughters of the Nakba," the third generation, born between 1954 and 1968, is a generation of political hope and activist momentum, infused with optimism and a sense of possibility. Sometimes known as the "Saudi generation," these women came of age during the 1970s and 1980 s, decades of relative prosperity in Jordan. Mass migration of Palestinian labor to Saudi Arabia and the Gulf-and their remittances to relatives back in the camps-created new life conditions encouraging the spread of a new conjugal model. ${ }^{18}$ With the development of the Jordanian and United Nations Relief and Works Agency (UNRWA) school systems, education became available to the majority of the population for the first time: while the level of education of Palestinian camp women had been lower than the national Jordanian average in previous generations, for this generation it was much higher. ${ }^{19}$ Also important was the impact of the Palestinian national movement, which had been rebuilt in exile and was quickly spreading to the camps: this atmosphere of revolution and renewal left a profound mark on the entire generation. All of these factors contributed to rebuilding self-esteem and dignity in the refugee population, allowing for an unprecedented individualization of women's choices and life paths. Traditional social norms began to be challenged, with calls for a new kind of relationship between men and women.

Changes were seen in a number of areas. Women of the third generation married later than before-many married after the age of twenty and about 10 percent married after thirty. Frequently they also made their own choice of spouse: a third of this generation's married women met their husbands within their own social networks (education, activism, profession). It was among this generation that for the first time love between husband and wife was represented as a social value, a desired (and sometime lived) feeling, in some cases leading to the formation of the couple as a more independent entity and a counterpower to their families of origin. But it was also a generation marked by increasing matrimonial disputes and separations and by the rise of celibacy: approximately one-fifth of my interviewees were either divorced or separated, and one-fourth were unmarried.

The period of intensive Palestinian political activism in Jordan was brief, from 1967 until 1971, when the fedayeen were driven out by the Jordanian army following Black September (1970) and the ensuing civil war. Nonetheless, Palestinian political activism continued to be a powerful force in the camps for the next two decades, mainly through the professional associations and underground political parties that continued to thrive. This was at least partly due to the political and military power of the resistance in Lebanon, and to the vast web of links between camps, activists, and militants in the two countries. The special atmosphere of these years is evident in Aida's description of the "militant outburst" of her adolescence: 
We felt free and most of the women took part in the revolution in the camps. They followed military training, were [dressed in] military uniforms, were going and coming freely, everywhere. $^{20}$

The resistance movement was primarily concerned with national issues and mobilization. In its interactions with the camp families, which it perceived as conservative, it did not challenge traditional social norms. This was especially true of Fatah, less so of the leftist factions, which were more socially progressive. Still, the impact of the national movement's presence on social change in the camps was great, if indirect. The historical guilt felt by the first generation for leaving the land made it easier for the third generation involved in national resistance activities to call for a social revolution against the previous so-called "traditional" mentality. The organizations associated with the resistance and the various activities they sponsored also constituted the main sites where women could socialize and individually choose a spouse, some breaking with family networks and customs.

Aïda's story illustrates the mixed role of the resistance. As a nationalist and feminist activist, she met her future husband, a journalist and writer, in the 1980s at the Jordanian Writers' Union. She was able to decide by herself to marry him because of the consideration, good reputation, resources, and power her militant activities earned her with her family and in the camp. Her status was further enhanced by her education and the fact that she was an English teacher. Yet her Fatah party comrades did not support her when she chose to break with social customs by not having the usual marriage and wedding celebration (boros). Her account shows the importance of breaking with traditions and customary norms, that is, of distancing oneself from collective belonging to form an independent couple and love relation and build its complicity and privacy:

We made a small party at home [at her parents' house]. Bassam and I did not wear wedding clothes, we danced together and we kissed in front of everybody [which was and still is not appropriate in public]. I wore a gold bracelet belonging to my sister [instead of the gold jewels that her husband should have bought for her] and I had a symbolic one-dinar dower (maber). ${ }^{21}$ After that, all the girls of the family got married with only a one-dinar maber. ${ }^{22}$

The impact of the Palestinian national movement in Jordan began to wane after the fedayeen were expelled from Lebanon in the wake of Israel's invasion in 1982. Though the social and political militant networks continued as matrimonial fields and places where customary practices could to an extent be challenged, at least by a small minority, for most women, political socialization declined further. Matrimonial choices made within activist networks, 
now perceived as dangerous, were valued less and became more difficult to impose on families.

Moreover, the Jordanian state's strict monitoring of all secular political groups and activities after the expulsion of the fedayeen encouraged renewed reliance on community and conservative family values, resulting in a resurgent discourse of honor and virtue. ${ }^{23}$ The regime's emphasis on the family's political role aimed to reduce the influence of opposition parties, especially the secular culture of the Palestinian movements and pan-Arabism. ${ }^{24}$ At the same time, the Muslim Brotherhood's social and charitable activities were allowed to spread their conservative religious values, especially in poor areas like the camps. This backlash played a significant role in the contradictions experienced by the third generation.

Indeed, the individualization of choice and the emergence of the couple and conjugal love as social values had only gone halfway for this generation. Thus, even as women were making individual life projects, acquiring education and economic resources, their trajectories were being socially reinscribed in family and conjugal-becoming, that is, in community and collective destiny. For most families, the identity value given to education and political activism for a time obscured their long-term effects on women's socialization in terms of individualized aspirations. The national movement itself, whose presence had on the one hand empowered women, also contributed to their consignment to the domestic sphere. By giving women a key function in the preservation of Palestinian cultural identity and authenticity, ${ }^{25}$ the movement politically invested their "traditional" roles and starting in the 1980s politicized their maternal role. ${ }^{26}$

Meanwhile, attitudes toward marriage within the third generation were themselves undergoing change. Young women, who now had higher expectations and wanted both a happy marriage and to be able to make their own life choices, began to see and experience contradictions. Having a personal trajectory came to be seen as antagonistic to marital life. Izdihar and Amal, for example, were profoundly affected by the fate of their older sister Halam. Very beautiful, successful at school, and gifted at drawing and painting, Halam had a special place in the family. Fulfilling her father's expectations, she had married her uncle's son (ibn 'am) when she was nineteen. She agreed to the marriage on the condition that she would at least finish secondary school, but soon after the wedding her husband refused to let her sit for the baccalaureate (tawjibi) exam. He then prevented her from pursuing any personal activity. Her broken fortune and her life of successive pregnancies and conjugal, moral, and physical violence led her sisters to see personal choices as incompatible with married life. In their account, the episode of her husband smashing her paint brushes and materials is emblematic of this antagonism.

The high expectations fostered in the third generation affected marriage patterns in various ways. For some, they led to postponing or even avoiding marriage. A quarter of the women I interviewed from this generation had wanted to marry for love, and half of them did. But for others, disappointed 
expectations contributed to their remaining single. Often, as seen in their accounts, this choice allowed them to maintain an idealized, romantic vision of love between men and women.

Izdihar was born in 1960. She decided not to marry when she turned thirty. She had given priority to her political involvement and to finishing her education so she could be an Arabic teacher. The time she devoted to these two paths-both of which her father opposed-led her to postpone marriage, which she saw as secondary. In the course of her activism, she met a man at the Jordanian Writers' Union and fell in love with him. When he left for America some time later she gave up the idea of marriage altogether. As an intellectual and nationalist activist, she was not ready to renounce her romantic ideal of marriage for a marriage of convenience; nor was she willing to subjugate her strong personality.

Amal, her younger sister, born in 1968, wanted to marry for love but was more pragmatic. Her idea of marriage was based on the centrality of the conjugal bond, understood in a more functional way as a space for new social gender roles for both spouses in a "modern" family. As a practicing Muslim, she also saw the couple in terms of Islamic law and spirit. After studying English in a community college, she worked as an English teacher and then as an assistant manager for a private company. The first man who wanted to marry her was her paternal uncle's son. Despite her father's insistence, she refused. Later, she fell in love with a close relative of a colleague. She saw him for a while but kept the relationship secret, and it did not last. She was thirty at the time. As she wanted to have children and worried about being too old for marriage, she began to attach less importance to love and more to the qualities she wanted in a husband: kindness, a good job, not a relative, and-since she did not want to remain in the camp-not a camp dweller. One of her colleagues proposed that she meet her brother, a forty-year-old engineer who was a nice person albeit suffering from chronic depression. She thought he was somebody she "could love, once they will be wed," but changed her mind after considering the risks of such a marriage. Later, when she was in her mid-thirties, she married for love a man she met in Qatar, where she had moved on her own to work for the ministry of education.

This generation also began to challenge earlier ideas about marriage as

For some of this generation, the perceived incompatibility of a personal trajectory and married life was reason not to marry. The desire for conjugal love also contributed to the emergence of female celibacy. mandatory or as a life commitment. For some, the perceived incompatibility of a personal trajectory and married life was reason not to marry. The desire for conjugal love also contributed to the emergence of female celibacy; though most often a choice, celibacy was also a function of the persistence of unwanted social constraints influencing marriages. Women who began by postponing marriage often ended up not marrying at all. Although celibacy has increased in Jordan and the Arab world, it was unusually high in the camps: for this age group, the statistical brackets 
I constructed from my anthropological data show a female celibacy rate in the camps twice as high as the Jordanian national average. These contradictions, and couples' difficulties in carving out a social space for themselves, are similarly manifested in the emergence of divorce and separation within this generation, also at levels well above the Jordanian national average. ${ }^{27}$ Indeed, statistics for Jordan and most Arab countries indicate decreasing divorce rates in the late twentieth century. ${ }^{28}$ As already noted, divorce was virtually absent in previous camp generations, although some women were separated. These trends show the specificity of matrimonial and social practices in Palestinian refugee camps in Jordan.

Overall, patriarchal family power was shaken and challenged by the individual choices of family members of this generation, leading to the emergence of a counterpower constituted by the nuclear family and the value attributed to the couple, both of which had been encouraged by changing lifestyles and social values in Jordanian and Palestinian societies and more widely in Arab societies (spread for instance by the media, movies, or various television series). These changes increased the sources of conflict between women and their families, within couples, and between the couple on one hand and the spouses' families on the other. In the experiences of the third generation, the conjugal relation began to be perceived as highly conflictual. Marital separations became relatively common. Physical or psychological abuse and violence were often mentioned in the interviews. While greater openness in talking about such matters undoubtedly contributed to these accounts, it is also not surprising that the redefinition of gender roles and family values resulted in a rise in conjugal violence, given the centrality of the matrimonial bond.

\section{A Pragmatic and Disillusioned Fourth Generation}

The women of the fourth generation, born between 1969 and 1983, experienced not only the social contradictions of the third generation but also the economic pauperization of the 1990 s caused by the involuntary return of most Palestinian workers from the Gulf states following the Gulf War, as well as by the effects of Jordan's economic policies of structural adjustment. The impact of the economic decline was compounded by the sense of political fragmentation and abandonment created by the Oslo agreements, which camp residents (above all 1948 refugees) saw as having excluded them. Meanwhile, economic insecurity, once again undermining men's ability to fulfill their roles as heads of families and breadwinners, led to an increased contestation of male authority.

At the time of my fieldwork, it was widely claimed that the individualization of the choice of spouse had become the rule inside the camps, with the parents now obtaining their children's agreement before engaging them in unions. ${ }^{29}$ This was not borne out by my findings. Of the young women I interviewed in this generation who were already married, more than half considered their marriages to have been decided by their families. These unions were generally 
contracted before the bride was twenty, even at fifteen or sixteen years old, as early marriages have become more frequent again. ${ }^{30}$

With the economic decline, personal ambitions for this generation have been limited by the scarcity of professional and marriage opportunities. Most have adapted their expectations accordingly. Their ideas about life and marriage are more pragmatic. Marriage for love is seen as utopian and not expected. According to Afsa, "When people do love each other, there are always problems and they do not marry. Each time I hear about love, it's like this." ${ }^{31}$ Hind, who was born in 1969, devoted most of her energy to her job at UNRWA, perhaps as a way of avoiding marriage, though she did not say so. When I asked her about marrying for love, she laughed, hiding her embarrassment and her buried illusions. "No, no, I do not want to marry for love. I can marry like that, normally ('adi). Nowadays, anyway, there is no more love. Only money counts." 32

Yet for most of these young women, the marriage bond is again crucial-the life path most desired. Most of those who are still single fear becoming spinsters. For the previous generation, female celibacy was most often a choice, a result of the higher priority accorded to education and professional, associative, or militant activities. For the fourth generation, however, as the pursuit of personal ambitions outside marriage is more difficult for economic reasons, celibacy is dreaded, seen as imposed by an unbalanced matrimonial market. ${ }^{33}$ Economic precariousness has also changed how women's work is perceived: once again, it is associated with need in response to family hardship (rather than personal fulfillment) and is therefore less valued.

Marriages for the second generation were ruptured by early death among the men, and for the third by separation and divorce then on the rise. Starting from this generation, that is, since the 1980s, broken marriages have not been followed by remarriage. This fact, combined with the rise of female celibacy, has led to a feminization of camp families. In Jabal Hussein and Gaza camp, about a third of the families are headed by women. Taking into account cases where the husband has either migrated abroad or is unable for health or other reasons to sustain his family, more than half of the camp families in the first years of the twenty-first century were headed by women.

\section{Protection and Conjugal Love}

The individualization of choice that has become prevalent since the third generation has a number of consequences for couples because of the persistence of family influence with regard to marriage. In most conjugal disputes, family interference prevents young couples from building and living their relationship and love (whether or not this feeling existed prior to marriage). The existence of a self-contained couple, and above all, of the feelings that forge two spouses into a single unit, are often seen as a threat to the families of origin. Such couples challenge not only the customary, more functional conjugal bond, but also the family's role, which has already been seriously weakened 
by social change in exile. Thus, in a context where the matrimonial system remains under family control and influence, love can become a social threat.

For families, the logic determining unions (whether chosen or not) generally gives priority to social relations as a whole, which remain guided by the same kinds of strategies that have governed matrimonial practices in the past. Unions are often perceived through a superiority/inferiority prism in which the families' social status is at stake; unions are often forged precisely to defend status and position. As a result, matrimonial politics are riddled with status and role competitions and involve unending social evaluations. These factors and the role of the family deeply undermine the couple's inner space and intimacy.

Yet at the same time, marrying outside the family or without family protection can have grave consequences. This is especially true for Palestinian refugees in Jordan, where the social and political system is specifically based on the power of family groups, ${ }^{34}$ and where protection is closely related to "social honor" (sharaf). Social honor is built on social identity (having a known family, place of origin and of habitation, specific political representation ${ }^{35}$ ), and what it really signifies is the protection afforded to individuals by the social or family group to which they belong. Camp families, being excluded from what constitutes social identity in Jordan, are thus seen as lacking in social honor, which clearly affects the social evaluations at stake in marriage and relationships. The impact of this situation is far greater for women, who lack protection both at the level of gender and at the level of their social group.

During militant years, the Palestinian resistance in Jordan played this protective role by giving a political identity to camp inhabitants; it is no accident that it was during the Palestinian revolution that love stories in the camps first came to light. Since the departure of resistance, the social stigmatization of the camps and their inhabitants returned in full force. Thus, social standing undermined individual social relations, especially between camp dwellers and people outside. With specific regard to marriage and love, the economy of both social relations between the two groups and gender relations in general means that building a relationship without family protection holds considerable risks.

Samar's short-lived marriage with Haytham illustrates the difficulties faced by young women who marry outside traditional family (or at least familyknown) networks. Samar hastily decided to marry Haytham in 1999 when she turned twenty-seven and did not want to remain single. Her father was deceased and she had no one to assert her family's social status or establish social equality with her prospective husband's family. Haytham was of Palestinian origin, appeared to Samar kind-hearted and open-minded (he opposed women's wearing of the hijab), and moreover did not live in the camp, leading her to disregard certain warning signals, such as a lack of real dialogue between them, and his criticism, even before they wed, of her allegedly inadequate observance of the prescribed social practices toward his widowed mother, with whom they lived after marriage. Samar soon became the target of her motherin-law's stigmatization of camp residents, especially camp women, who were characterized as being without honor. Her behavior was constantly criticized, 
and she was even called a "girl from the street" (bint min al-shara). Her husband meanwhile refused her requests for clothing or other articles on the grounds that, as someone from the camp, where poverty reigned, she should not have such needs. This was particularly galling as her father had been known as a merchant and traditional shaykh, and her family enjoyed a high status in their village of origin and in the camp. The relationship quickly deteriorated, ending in divorce.

Matrimonial and social politics inside and outside the camps, and within the broader Jordanian and Palestinian contexts, contribute to the fragility of trust between men and women and between spouses or fiancés, which in itself further infringes on couples' privacy and intimacy. Indeed, love can scarcely be lived when protection and honor are overriding concerns to the point that they stifle or constrain individualities. Yet love is equally unlikely when social and political protection is absent or weak, as has been the case for Palestinians in the camps since the resistance left and even more so since the Oslo agreements. Back in the 1950s, sexual honor (' $i r d$ ) had been given a greater role in Jordan's refugee camps to counterbalance the older generation's sense of loss and guilt at leaving the homeland. Decades later, as of the 1980s, it again received emphasis to counterbalance the loss of political protection, the social stigmatization arising from a perceived lack of social honor (sharaf), and the political marginalization on Jordanian and Palestinian national scenes.

Sometimes, these larger issues spill over and affect marriage choices, couples, and feelings, imposing their social injunctions and their violence. The result can be separations, tensions, conjugal violence, or simply the impossibility of living a harmonious relationship, even if those involved wished otherwise. Thus does this account of marriage and love question the extent of agency and consent both in men and women's choices and in the historical reproduction of patriarchy.

\section{Notes}

1. See, for instance, Hans Medick and David W. Sabean, eds., Interest and Emotion (Cambridge: Cambridge University Press, 1984) and the works of Catherine Lutz. See also Bernard Vernier, La genèse sociale des sentiments. Aînés et cadets dans l'île grecque de Karpathos (Paris: Éditions de l'EHESS, 1991); and Pierre Bourdieu, who tackles this issue in Méditations Pascaliennes (Paris: Seuil, 1997) and in La domination masculine (Paris: Seuil, 1998). Since 2006, historians from the EHESS in Paris, such as Cécile Dauphin, Jocelyne Dakhlia, and Arlette Farge, have conducted a seminar and several workshops on the history of love. On the Middle East and the way the system of honor and social hierarchy among Bedouins in Egypt is also reproduced through discourses on emotion, see Lila Abu-Lughod, Veiled Sentiments: Honor and Poetry in a Bedouin Society (Berkeley, Los Angeles, and London: University of California Press, 1988).

2. On family history, relations, and networks in the camps, see Stéphanie Latte Abdallah, Femmes réfugiées palestiniennes (Paris: PUF, 2006).

3. Prohibitions concerning relations and sexuality outside the marriage frame are quite powerful in the camps, notably for women, on whose perceptions this article is centered. 
4. Author's translation of Maurizio Gribaudi, Itinéraires ouvriers. Espaces et groupes sociaux à Turin au début du XXème siècle (Paris: Éditions de l'EHESS, 1987), p. 141; see also Latte Abdallah, Femmes réfugiées palestiniennes.

5. See Rosemary Sayigh, "Palestinian Camp Women's Narratives of Exile: Self, Gender, National Crisis" (PhD dissertation, Department of Sociology and Social Anthropology, University of Hull, 1994).

6. The fieldwork was conducted mainly between 1999 and 2002 for my PhD dissertation in contemporary history, "Destins de femmes et liens familiaux dans les camps de réfugiés palestiniens en Jordanie 1948-2001" (Paris: EHESS, 2004). A major part of this study has been published in Latte Abdallah, Femmes réfugiées palestiniennes.

7. Male and female celibacy was nonexistent in Hilma Granqvist's ethnography of the village of Artas, and women generally remarried after widowhood and divorce (82 percent). See Hilma Granqvist, Marriage Conditions in a Palestinian Village (New York: AMS Press, 1975).

8. These statistics have been constructed out of anthropological data based on a sample of 54 families and 78 women. Among them, 11 women belong to the first generation, 18 to the second one, 21 to the third one, and 28 to the fourth one. Although the number of women who have been interviewed in depth is limited, this sample was chosen according to the sociological diversity and characteristics of families and women of the camps. Though the statistics constructed do not constitute precise figures, they form reliable brackets and trends. For the whole data and charts, see Latte Abdallah, Femmes réfugiées palestiniennes, pp. 229-230.

9. According to a then-widespread custom, a man coming to a house looking for a bride does not necessarily know which of the single girls will be presented to him.

10. Author interview with Umm Muhammad, Jerash Camp, 10 June 1999.

11. Sayigh, Palestinian Camp Women's Narratives of Exile, chapter 6.

12. The man had been married by "exchange" (badil), where two members of one family marry two members of another by reciprocal agreement between the families. These marriages are based on the equality and reciprocity of both unions.

13. Author interview with Hajji Myriam, Jabal Hussein camp, 8 February 1999.

14. Author interview with Hajji Myriam, Jabal Hussein camp, 8 February 1999.

15. Author interview with Umm Adnan, Jabal Hussein camp, 11 January 1999.

16. Author interview with Ibtissam, Jabal Hussein camp, 10 November 1999.

17. Only one of the women, Umm Sufian, had separated (while in her fifties) from her husband. More than a third of our interlocutors were widows, compared with 15.3 percent for Jordanian women of the same age group. See the Hashemite Kingdom of Jordan Department of Statistics, "Study on Life Conditions in Jordan. Preliminary Report. Main Results" (October 1996).

18. During this period, migrations were also mainly familial: married men would bring their wives and children with them.

19. Of the interviewees, 33 percent graduated from secondary school, 24 percent went to community colleges, and 9.5 percent entered university. In Jordan, only 12.7 percent of the women in this age group completed secondary education, 13.7 percent earned postsecondary diplomas (mainly from community colleges), and 5.9 percent entered university. See the Hashemite Kingdom of Jordan Department of Statistics, "Study on Life Conditions in Jordan." For detailed charts and comparison, see Latte Abdallah, Femmes réfugiées palestiniennes, pp. 229-230.

20. Author interview with Aïda, Amman, 3 December 2000. Leyla Khaled, a Popular Front for the Liberation of Palestine activist and leader, recounts in her autobiography how she met and fell in love with her first husband, an Iraqi who fought with the Palestinian resistance, at a mixed military base and training camp in Ajlun, northern Jordan. They even decided to get married without telling their families, the only consent being that of resistance members. See Leyla Khaled, Mon peuple vivra. L'autobiographie 
d'une révolutionnaire rédigée par Georges Hajjar (Paris: Gallimard, 1973).

21. For Aida and most feminists, the dower is rejected as a transaction between families denoting the purchase of the bride.

22. Author interview with Aïda, Amman, 6 April 2000.

23. Laurie Brand, Women, the State, and Political Liberalization: Middle Eastern and North African Experiences (New York: Columbia University Press, 1998), p. 124.

24. Political Islam was targeted only after its opposition to the Oslo and Israeli-Jordanian peace agreement.

25. See Latte Abdallah, Femme réfugiées Palestiniennes; Deniz Kandiyoti, ed., Women, Islam and the State (Philadelphia: Temple University Press, 1991).

26. See Julie Peteet, Gender in Crisis: Women and Palestine Resistance Movement (New York: Columbia University Press, 1991).

27. At the time of my research, 54 percent of the interviewees were married (two married twice, one after being widowed and the other one after a divorce), 14 percent were divorcees, 5 percent were separated, and 24 percent were single. At the Jordanian national level, 1.8 percent and 0.7 percent of the women of the same age group are respectively in these situations, and $\mathbf{1 0 . 5}$ percent are not yet married. See for these figures the Hashemite Kingdom of Jordan Department of Statistics, "Study on Life Conditions in Jordan." For a detailed comparison, see Latte Abdallah, Femmes réfugiées palestiniennes,

pp. 229-230.

28. See Philippe Fargues, Générations arabes. L'alchimie du nombre (Paris: Fayard, 2000), p. 129 and pp. 142-46.
29. This had always been a requirement under Islamic law, but the practice was now claimed to be honored.

30. It is not possible to be more precise about celibacy rates for this generation, which at the time of my fieldwork was still at the age when many marry.

31. Author interview with Afsa, Jerash camp, 3 December 1999.

32. Author interview with Hind, Jerash camp, 10 April 1999.

33. Though further study is required, the dearth of men can be attributed to several factors: the economic difficulties faced by young men to collect enough money to marry, the will to marry women outside the camps, and emigration abroad for study or work.

34. Lama Abu-Odeh has shown the role of honor in the penal code, and more broadly the function given to private justice. She highlighted how Jordanian elites drafting the juridical system reproduced tradition and contributed to the emergence of a new nationalist patriarchy system where the role of women is modernized but submissive to the family institution, which is the basis of national culture. See Lama Abu-Odeh, Feminism, Nationalism and the Law: The Case of Arab Women, PhD dissertation (Cambridge, MA: Harvard University, 1993); "Crimes of Honor and the Construction of Gender in Arab Societies," in Mai Yammami, ed., Islam and Feminism: Legal and Literary Perspectives (London: Ithaca Press, 1996), pp. 141-94.

35. This can include minority seats (such as Bedouin, Christian, Circassian) in parliament, which the camps did not have (though they may have representation within the general context of electoral districts). They thus have no direct access to political power. 